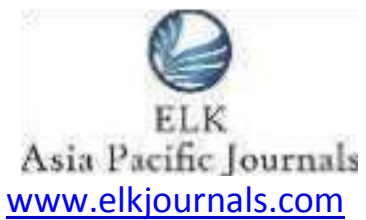

\title{
THE EFFECTIVENESS OF USING THE JOHNNY APPLICATION ON THE ACADEMIC ACHIEVEMENT OF STUDENTS LEARNING THE ENGLISH LANGUAGE INTERMEDIATE SCHOOL STUDENTS IN MAKKAH CITY
}

\author{
Wafaa Musallam Al-Hejaili \\ English language Supervisor \\ Saudi Arabia- Makkah \\ Email Id- hjlwafa@yahoo.com
}

\begin{abstract}
Teaching and learning of English language among ESL students is a domain of academic research that has sought attention of various investigators, where non-conventional methods of teaching are largely explored. Considering the relevance of learning English language with innovative methods, this research has been conducted to assess the impact of using the Johnny application for teaching English to intermediate schoolgirls in Makkah city. The study further aims to understand and evaluate the reaction of the students and their parents towards the application. For this purpose, the study adopts a quantitative research approach and finds that the students using Johnny application experienced better understanding towards the language and developed their English language skills. The Johnny application is a very effective method for teaching English to intermediate school students, as agreed by not only the students, but also the parents and teachers.
\end{abstract}

\section{INTRODUCTION}

Currently, there has been an increased interest in language studies because language is the main method of gaining knowledge, developing experience, communicating or exchanging ideas and preserving human heritage. Moreover, it has a profound influence on individuals' personalities.

Because there are many different languages, it is important to learn foreign languages. The English language is very important, as it is the most commonly used language around the world. English is the official language of communication between many countries, in conferences and political meetings, in research and publications, as well as in trading and the economy (reference). In general, many countries consider using one or more

Foreign languages to facilitate communication with the outside world. 
The literature shows that learning the English language is essential to cope with current technological advancements. Researchers can learn a foreign language in addition to their native language. Costantino (1990) states that learning languages is a natural process because individuals tend to learn different languages by default to communicate with each other.

Cooper (1987) states that the pupil that learns a foreign language shows better results in preliminary school exams than those do not.

In the Kingdom of Saudi Arabia (KSA), education officials have recognized the importance of learning foreign languages, especially English. Since 1359H, the KSA (presented by the Ministry of Education (MoE), including all departments in the $\mathrm{MoE}$ ) has made huge financial investments to help MoE pupils learn the English language and gain the appropriate skills to use it. MoE developed English language curriculums for the intermediate and secondary stages. MoE also prepared different learning tools and methodologies that meet the latest modern theories in education to help with the process of teaching the English language. MoE has also developed language laboratories for English in intermediate schools. Moreover, experts from both Arabic and foreign countries had been hired to help in teaching the English language, as well as Saudi graduates from various Saudi universities.

Besides that, MoE regularly monitors the programs and aims for continuous development in the curriculums, along with intensive training for workers in this field. However, regardless of the huge efforts made and the constant support to form an infrastructure for teaching the English language, there is a gap between the current level of students and the targeted levels, mainly due to the low level of students in the intermediate schools. This drives the necessity for research and investigation into the required changes in the methodologies needed to enhance the education level and achieve the best results.

There are few studies in this field that investigate technical applications for teaching English. Based on the knowledge gap in this area, this study will investigate the influence of using the Johnny application in English language learning for intermediate schoolgirls in Makkah and the reaction of the pupils and their parents toward this application.

\section{RESEARCH PROBLEM AND RESEARCH QUESTIONS}




\section{Research Question}

- This research will assess the impact of using the Johnny application for teaching English to intermediate schoolgirls and the reaction of the students and their parents towards it.

- Based on this question, the following questions will be answered, accordingly:

- Is there a statistical difference ( $\alpha \leq$ $0.05)$ between the average trial students' marks (those who used the application for vocabulary and grammar) and the standard students' marks (those who did not use the application) in the dimensional measurement of the achievement test?

- Is there a statistical difference $(a \leq$ $0.05)$ between the average trial students' marks (those who used the application for spelling) and the standard students' marks (those who did not use the application) in the dimensional measurement of the achievement test?

- Is there a statistical difference ( $\alpha \leq$ $0.05)$ between the average trial students' marks (those who used the application for learning English) and the standard students' marks (those who did not use the application) in the dimensional measurement of the achievement test?

- How effective is the Johnny application for teaching English to intermediate schoolgirls?

- What is the sentiment of the intermediate schoolgirls who tried learning English using the Johnny application toward the application?

- What are the parents' sentiments towards using the Johnny application in teaching their daughters English?

\section{LITERATURE REVIEW}

In general, people in a country who speak foreign languages can communicate easily with people from other countries, interact with those people and perform economic operations; this is especially true with the English language, which is the official language for research and other sectors. Lenjaui (2001) notes that English is the language of the Internet because it is five times more common than any other language available on the Internet. The Internet is a channel for instant communication around the world, and there are more users joining the Internet daily. 
Additionally, many well-known computer applications are presented in English.

\section{IMPORTANCE OF LEARNING ENGLISH LANGUAGE}

The technological revolution, characterized by the developments in personal computers and the Internet, along with the use of video and digital multimedia equipment, has a major goal of exchanging and distributing information. English is the main language used in all of these applications, which indicates the importance of learning English to benefit from the information available through this media. Almina (2002) argues that, "English is a worldwide communication language, so it is used in the Internet, because it is flexible, easy to learn and accept; thus, it is more common around the world. Also, it is more common in management, as all of the current theories and ideas within the management, finance, trade and industrial sectors are written and documented in English" (p. 4).

Kitoe (2003) notes that there are more than 350 million English native speakers worldwide and that more than 400 million speak English as their second language. Kitoe (2003) also argues that, due to the importance of English, the number of people using English as a second language is greater than the number of native English speakers. Hence, English can add to the knowledge regarding scientific inventions, expertise and experiments, and it can help accelerate these developments. Alzaidi (2003) argued that, "The educational and scientific level in any society will be limited to what it possesses of sciences and evolution in the language as an infrastructure for research, education and social and knowledge developments" (p. 149).

Accordingly, learning English is every important; however, we must not forgot about our tongue language, Arabic, as the Holy Quran is in Arabic.

\section{JOHNNY GRAMMAR'S WORD CHALLENGE APPLICATION}

The Johnny application offers a versatile set of features that help students develop positive behaviour and enhance their skills and attitudes; this application also helps students form relations between concepts within the language. Hence, using the application allows for the following:

- The development of the students' mental and physical abilities, ability to fulfil their desires, and gain skills in different fields, as well.

- The ability to transform knowledge and activities into behavioural skills. 
- Self-directed learning using visuals and practice, and learning by doing.

- Gradual learning to suit the students' unique abilities and the developments they achieve.

- The ability to repeat different activities, which will be useful to retain basic skills.

- An appreciation of self-learning among the students.

- The development of different skills by using different activities.

- The ability to accommodate the students' different abilities.

\section{PREVIOUS STUDIES}

\section{Salem Alzahrani (2009)}

This study investigates the importance of educational aids in teaching English in intermediate schools. The study also investigates the extent to which schoolteachers employ educational aids in intermediate schools. Moreover, the study identified the challenges that hinder the use of educational aids in teaching English in Jeddah city.

The study concludes that the teachers have the required knowledge of educational aids; however, the number of educational aids in intermediate schools was limited only to three. In certain cases, there were more than three educational aids, but they were not available for use. In general, the financial cost was the most important factor regarding the use of educational aids in teaching English in intermediate schools.

\section{Ahmad Albanian (2003)}

The study intended to identify the level of English used in intermediate and secondary schools at public and private schools in Riyadh city. The study also identified the extent to which the student level was developed and if there were any statistical differences between the different groups of students, and the causes for these differences.

The study concludes that intermediate and secondary school students in private schools have a better understanding of English in contrast to their counterparts in public schools; the main reasons are the increased use of educational aids and more classes per week.

\section{RESEARCH METHODOLOGY}

This research will identify the effectiveness of using the Johnny application in teaching English to intermediate schoolgirls and the reflections of the students and their parents toward the application. 


\section{RESEARCH METHOD}

The researcher adopted a quasiexperimental approach to help identify the effectiveness of the Johnny application in learning English. Obidat, et al. (2003) defined this quasi-experimental approach as "a controlled change with defined conditions on a certain real case, or the case being investigated, and the monitor the changes as a result of the changes performed" (p. 310).

The research will investigate the effectiveness of the Johnny application in teaching English and the trend towards using it. Thus, a quasi-experimental approach is the most suitable to achieve the research objectives. This study depends on forming two equivalent groups: experimental and standard. Both groups performed the achievement test, and the experimental group only used the Johnny application. After the experiment period, both groups were challenged with a dimensional test; accordingly, a measurement evaluation of the trend of the students and their parents was applied dimensionally. By comparing the statistical results of both groups, it was possible to identify the independent variable as the Johnny application in teaching English and how this applicationan be used to increase the students' skills and their language achievements.

\section{STUDY POPULATION}

Alassaf (2003) states that the study population is "a scientific and systematic concept [that] covers all those who fall within the study domain, like individuals or groups of individuals, books, or schools, according to the context of the study problem" (p. 91).

Accordingly, the study population of this research is all female students in public intermediate schools in Makkah city, which is governed by the MoE for the second semester of the academic year $1435 \mathrm{H}$; the students' parents are included in the study population, as well.

\section{SAMPLES DOMAIN}

The samples domain consists of 100 students: the students of the 59 public intermediate schools. The samples have been selected intentionally. The students are divided into two groups: standard and experimental, with 50 students in each. The students' parents of each group are considered members of the corresponding groups. The details of the samples domain are shown in (Ref Table 1)

\section{STUDY DETERMINANTS (DEFINING IT AND TURNING IT)}

Jaber and Kadhem (2002) defined the determinant as "the description or characteristics that can have different values for different individuals or groups" 
(p. 168). This study includes the following determinants:

- Independent determinant: Represented as the experimental factor of using the Johnny application for teaching and learning English.

- Dependent

determinant:

Represented as the experimental group's performance on the achievement test and the trend of the students and their parents toward using the Johnny application in learning English.

- Calibrating the Determinants of the Study:

\section{Equivalence level between the groups: To}

guarantee the equivalence between the samples within the two groups, a pre-test was performed on all the study samples. The results of the two groups were evaluated using a statistical comparison to identify the differences between the averages of the two groups. A t-test was applied to perform the statistical analysis, as shown in Table 2.

Table 2 shows that there is no significant difference in the averages of the achievement test results between the two groups, as there was no measurable difference at the significance level ( $\alpha=$ 0.05). This indicates that the two groups are equivalent according to the pre-test results.

(Ref Table- 2)

- Teaching time (study period): The study period lasted for five weeks. During the study period, only the samples from the experimental group used the Johnny application.

- The teachers: The researcher and different teachers monitored the experimental group according to the Johnny application manual, a page on Facebook created so that the students could publish their results online. A group in the WhatsApp was created, as well.

- Study aid and material: To achieve the goal and objectives of the study, the researcher designed different tools and research material as follows:

- Achievement test: This test was used to measure English language skills.

- Develop a trend index: This trend index was used to measure the trend of the students and their parents toward the use of the Johnny application in learning English. 
PREPARING THE STUDY AIDS AND MATERIALS

\section{Preparing the Achievement Test}

This study will measure the effectiveness of using the Johnny application in teaching and learning English. Tests are one of the most common tools used to measure the success of the educational system. Abu Jado (2005) defines the achievement test as follows: "it is an organised procedure to identify what the student learned according to the defined objectives" (p. 249). The achievement test for the study population is prepared based on the following:

- Objective of the test: The test measures the ability of the intermediate school students to use the Johnny application (which includes the features that are appropriate for their level) and the effectiveness of using the application for learning the English language.

- Designing the test: A multiplechoice test of 30 questions was developed, of which 20 questions measure grammar skills and 10 questions measure spelling skills. Each question, if answered correctly, will have a mark of 0.5 , which makes a maximum of 15 marks for the test. The researcher considered the following to ensure that the test is clear: introduce the question, then the options; include clear question headers; ensure that questions are grammatically correct, short and diverse; include at least three options for each question; and ensure that the answers are randomly located among the options to avoid guessing the answers based on patterns. Table 3 shows the test details. (Ref Table- 3)

- Designing the test description: To clarify the test, a description to the test was introduced. The test description is one page outlining the test details and is included at the beginning of the test. The description indicates how the test should be answered. The researcher paid great care to provide a straightforward and clear description to facilitate the students' understanding of the test.

- Marking key for the test: The correctly answered questions were given a mark of 0.5 ; no marks were given for incorrect answers, or unanswered or deleted questions. 


\section{- Ease and difficulty factors of} the questions: Identifying the areas in which the test was easy or difficult shows that the test questions varies between easy, moderate and above moderate. Table 4 shows the difficulty levels of the test questions. The table shows that the ease and difficulty of the exams are 0.44 to 0.68 and 0.32 to 0.56 , respectively, which are accepted for both levels. This indicates that the test has the required diversity to measure the students' learning skills. (Ref Table- 4)

- Test stability: Cronbach's alpha coefficient was used to measure the test's stability, the results of which are shown in Table 5; the total stability of the test is very high at 0.89. (Ref Table- 5)

- Final form of the test: The test consists of 30 questions: twenty questions measure grammar skills, and 10 questions measure spelling skills. Each correctly answered question will have a mark of 0.5 ; thus, the maximum mark for the test is 15 . The test and its details are shown in Appendix A.

\section{TREND MEASURING INDEX}

This index measures the trend of the students and their parents toward using the Johnny application in learning English; the steps to develop the index are as follows:

- The index sentences: The index questions are formulated as reporting sentences, and the students and their parents report the degree of acceptance for each of the test questions. Likert methodology was selected as it is a common and easy method to measure the trend. The questions measure different issues regarding the trend toward the application. For each question, there are three options: agree, neutral and disagree.

- Forming the questions: The questions of the trend are form based on the following considerations:

- The questions should include the trend issue explicitly.

- The questions should cover the different behavioural issues of the trend.

- No direct facts should be mentioned.

- Questions should be less than 20 words each. 
- Each question discusses one issue.

- The language of the questions should be simple.

- Certain words should be excluded, like all, always, never, and anybody.

- Trend measuring index description: The trend index description includes examples of how to answer the questions, and the researcher emphasised the following: there are no right or wrong questions or answers, as all the answers represent the views of the students and their parents. There is no link between the results of the trend index and the result of the achievement test. The students and their parents should answer all questions.

- Trend measuring index accuracy: Each of the questions within the trend-measuring index was verified by measuring its relation to the overall accuracy and by ensuring that there was no conflict between them. This was verified using the Pearson correlation coefficient. (Ref Table 6) shows the verification

- The table shows that the trend of the students and their parents toward using the Johnny application in learning English language are 0.614 to 0.687 and 0.702 to 0.781 , respectively; this is considered high and reflects the strength of the correlation between the questions that are measuring the trend.

- Correcting the trendmeasuring index: Each answer was given a weight, as shown in (Ref Table 7). The total answer is the sum of the answers of all the individual questions.

- Trend-measuring index stability: The index's stability was calculated using Cronbach's alpha coefficient; the stability of the index for the students and their parent are 0.81 and 0.87 , respectively. These results are practically accepted and reflect high stability. Accordingly, the results of the study will be reliable.

- Trend-measuring index final form: The index's accuracy and stability were verified, and its description was clarified. The trend-measuring index for the students contains seven questions, as shown in Appendix B. Appendix $\mathrm{C}$ shows the index for the students' parents, which contains five questions. 


\section{IMPLEMENTING THE FIELD STUDY}

After preparing all the field study requirements, the researcher obtained the necessary permission to implement the study. First, the researcher developed a timetable for the study; the field study is based on a five-week period during which the Johnny application was used to learn English. During the field study, the researcher followed this procedure:

- Using the study description, the researcher identified the objectives of the study to the students, as well as its importance and main advantages. In addition, the researcher discussed the privacy issues with the students and confirmed that all the collected data will be limited for use in this study alone. The students had access to the study details to help them understand the experiments and to reflect on each step of the study.

- E researcher performed the preachievement test on both the standard and experimental groups.

- The results of both groups were collected and statistically analysed.

- The experimental group used the Johnny application during the field study, while the standard group did not.

- The post-achievement test was performed on both groups.

- The trend-measuring index was applied to the students in the experimental group.

- The trend-measuring index was applied to the parent of the students in the experimental group.

- All field study results were collected using the designed marking keys and statistically analysed. Statistical analysis was performed using the Statistical Packages for Social Sciences in SPSS.

\section{STATISTICAL METHODS}

For the purposes of statistical analysis, the researcher used the following tools:

- Cronbach's alpha coefficient: This was used to calculate the stability of the achievement tests and the trend-measuring index.

- Pearson correlation coefficient: This was used to measure the correlation between trendmeasuring index questions.

- The equation of ease and difficulty of the achievement test questions: 
- Average: This was used to compare the results of the achievements tests performed by the two groups.

- Standard deviation: This measured the difference between the achievement test results of the two groups to estimate the differences that can be calculated using the average.

- T-test: This identified the differences between the averages of the two groups' results in the achievement tests.

- Eta squared to measure the size of the impact: This measured the impact of the Johnny application on the students' achievements when learning English.

\section{STUDY RESULTS}

In this section, the results of the study will be introduced and discussed. The results of the statistical analysis will be introduced, as well.

\section{Question 1}

The first question of the study determines if there are any statistical differences between the results of the two groups in the post- achievement test at the level of $\alpha \leq 0.05$ when learning the grammar and vocabulary.

To answer this question, the averages and standard deviations of the postachievements test for the standard and experimental group are given for grammar and vocabulary learning skills. The results are shown in (Ref Table 8).

The table shows that the averages of the experimental and standard groups in the post-achievement test are 6.89 and 4.08, respectively. To investigate the statistical difference between averages of the two groups' results in the post-achievement test, a t-test was applied.

Ref Table 9 shows the results of the t-test, which has the value of T12.550 at $\alpha \leq 0.05$; this statistically indicates that the students of the experimental group obtained better results in the post-achievement test than those in the standard group. This difference exists because the students of the experimental group used the Johnny application, while the students of the standard group did not.

The results indicate that the students of the experimental group obtained better results in the post-achievement test compared to the standard group students, which reflects the effectiveness of using Johnny English in 


\section{ELK ASIA PACIFIC JOURNAL OF SOCIAL SCIENCE}

learning English. It is a positive indication that the Johnny application enabled the students in the experimental group to practice English vocabulary and grammar more efficiently. The ability to provide direct feedback when using the application also helped identify where the errors occurred to avoid them in the future. Moreover, using the Johnny application encouraged the students to focus during the learning process and to observe all the actions within the application; this helped the students to become more self-directed when learning English and to recall what they learnt for a longer period.

\section{Question 2}

This section will address the answers to the study's second question: is there any statistical difference between the results of the two groups in the post-achievement test at the level of $\alpha \leq 0.05$, when learning the spelling of English vocabulary?

To answer the second question, the averages and standard deviation of the postachievement test for spelling skills in English were calculated for both groups. The results are shown in Ref Table 10.

The table shows that the averages of the experimental and standard groups in the post-achievement test regarding the spelling skills are 3.46 and 1.98 , respectively. A t-test was used identify any statistical differences between the averages of the two groups; the results of the t-test are shown in Table 11.

The results shown in Ref Table $\mathbf{1 1}$ indicate that there is a positive statistical difference between the experimental group and the standard group at $\alpha \leq 0.05$, with a $t$ value of 13.746. This indicates that using Johnny English is effective for developing spelling skills because the students in the experimental group showed advancement in this area when compared to the students in the standard group.

The results of the averages and t-test indicate that there was a positive and significant development in the spelling skills of the experimental group in comparison to the standard group. Accordingly, the students in the experimental group showed improvements in their vocabulary, writing, grammatical and linguistic skills while using the Johnny application. In addition, using the application enhanced the students' knowledge of English more generally and stimulated their interest in using and remembering English vocabulary. Moreover, the students' ability to remember word spellings and the ability to use the words in the daily life significantly increased. 


\section{ELK ASIA PACIFIC JOURNAL OF SOCIAL SCIENCE}

ISSN 2394-9392 (Online); DOI: 10.16962/EAPJSS/issn. 2394-9392/2015; Volume 5 Issue 1 (2018)

\section{Question 3}

The third question of this study addressed whether there were any statistical differences at $\alpha \leq 0.05$ between the average of the experimental group and the standard group in the post-achievement test.

The averages and standard deviation of the results of the two groups in the postachievement test are shown in Table 12 (Ref Table- 12).

The results show that the average of a student from the experimental group is 10.35 compared to 6.06 for the standard group students. The standard deviation for the experimental and standard groups is 1.7357 and 1.4020 , respectively.

The t-test was used to identify any statistical differences between the results of the two groups, shown in Table 13. The results in Ref Table $\mathbf{1 3}$ demonstrate that the average of the experimental group is significantly higher than the results of the students from the standard group; the value of $\mathrm{T}$ is 13.595. This suggests that the students from the experimental group have a more advanced command of the English language when using the Johnny application to learn English.

These results show that the experimental group, who used the Johnny application to learn English, have more positive developments in learning the language that those in the standard group. In general, this is due to the effectiveness of using the Johnny application in learning English, as it enhances the ability to remember English spelling and grammar and how to properly use English words in the different situations. The students in the experimental group also developed the ability to create and form links between what they learnt from the Johnny application and what they already know.

The researcher argues that these improvements result from the use of the Johnny application, which drives selflearning among the students, enables the students to review concepts and ensures that they achieve the goals of the learning process. The application also helps students overcome different difficulties and engages them in the learning process.

\section{Question 4}

This section will address the following question: what is the effectiveness of using the Johnny application in learning English among intermediate school students?

To estimate the effectiveness of using the Johnny application in learning English, eta squared was used. Eta squared was applied to the results of the two groups in the pre- 


\section{ELK ASIA PACIFIC JOURNAL OF SOCIAL SCIENCE}

ISSN 2394-9392 (Online); DOI: 10.16962/EAPJSS/issn. 2394-9392/2015; Volume 5 Issue 1 (2018)

and post-achievement test; the result of eta squared are shown in Ref Table 14.

The results in Table 14 show that the impact of using the Johnny application in the postachievement test is 0.808 , which is relatively high. Kohen defined the minimum value of eta square as 0.14 to have effectiveness. The differences between the results of the two groups in the pre-and post-achievement tests are present because the experimental group used the Johnny application, while the standard group students did not.

Accordingly, using the Johnny application has a significant impact on self-learning of English, and it can noticeably increase the achievement of the students in the intermediate schools. This increase in learning and achievement results mainly from the fact that the student controls the learning process and is also in control of planning, monitoring and self-adjustment; thus, the students are stimulated to finish the learning process using the Johnny application.

\section{Question 5}

The fifth question of the study addresses the trend of intermediate school students toward using the Johnny application in learning English.
Ref Table 15 shows the averages and standard deviations of questions from the trend-measuring index performed by intermediate school students using the Johnny application for learning English.

The results show that the averages of the students' answers for the seven questions varies between 2.34 and 2.94, with a general average for all questions of 2.66 and standard deviation of 0.650 . According to the index, the intermediate school students show a significant trend towards learning the English language using the Johnny application. There were a high number of responses from the study sample to all trend-measuring questions. The results of the trend-measuring questions indicate that the Johnny application enhanced the students' achievements, engaged students with the learning process and stimulated their minds, concentration and awareness of what they achieved. In addition, the level of control that the students had in the learning process helped develop and enhance their skills.

\section{Question 6}

The sixth question of the study is as follows: what is the trend of the parents of the intermediate school students toward using the Johnny application when learning English? 
The averages and standard deviation of all the questions that measured the trend of the parents toward learning English using the Johnny application are shown in Ref Table 16.

The results show that the averages of the parents' answers vary from 1.96 to 2.92 , with a general average of 2.60 and standard deviation of 0.574 According to the index, the trend of the parents toward using Johnny English in learning English language is very high, although the answers of the samples fall in two scales: high and intermediate.

These results indicate that the parents' involvement in the learning process is higher when they can monitor the progress of their daughters' learning. The increased confidence the students have when learning English using the Johnny application had a positive impact on their achievement, which eventually increased the parents' involvement with the learning process and how it can be monitored and controlled.

\section{CONCLUSION}

The most important conclusions of the study can be summarised as follows:

- There are significant statistical differences in the averages of students who used the Johnny application to learn English grammar and vocabulary and those who did not. Students who used the application experienced significant benefits.

- There are significant statistical differences between the averages of students who used the Johnny application to learn English spelling and vocabulary and those who did not.

- There are significant statistical differences in the averages of the students who used the Johnny application to develop their English language skills.

- The Johnny application is a very effective method for teaching English to intermediate school students.

- There is a high degree of acceptance in using the Johnny application to teach English to intermediate school students, as well as their parents.

\section{RECOMMENDATIONS}

Based on the observations of the study and its conclusions, the researcher recommends the following for future research in this area:

- Increase the awareness of using educational applications among 


\section{ELK ASIA PACIFIC JOURNAL OF SOCIAL SCIENCE}

ISSN 2394-9392 (Online); DOI: 10.16962/EAPJSS/issn. 2394-9392/2015; Volume 5 Issue 1 (2018)

the students and encourage them to use it for self-directed learning.

- Arrange training sessions for intermediate school students (as well as other students generally) in the use of the Johnny application to learn English.

- Facilitate increased awareness of the students regarding the use of different educational applications to learn English language.

- Arrange for competitions among the different students in intermediate schools; these competitions would focus on learning English using the Johnny application and would help encourage them to use these applications.

\section{FUTURE WORK}

The researcher believes that there is little interest in the field that investigates the use of educational applications in the learning process. Accordingly, it is important to perform the following studies in the future:

- Investigate the effectiveness of using other educational applications in the learning process of the English language and other topics.
- Investigate the use of the Johnny application in learning English language among the primary and secondary schools.

\section{REFERENCES}

- AlBenyan , Ahmad (2003): Saudi Students` level in English Language in the Intermediate and Secondary stages public and private schools, King Faisal Scientific Magazine, chapter four, first edition

- AlHazmi, sultan (1426): Teaching English language in the elementary stage in Saudi Arabia, annual study, teachers`college in Abha, seventh edition 1425-1426AH.

- AlZahrani, salem: The Intermediate stage teachers point of view on Teaching Aids in Jeddah, unpublished master's thesis: Makkah Umm AlQura UniversityEducation College

- AlAwadi, khaled(1420): Teachers point of view on teaching English problems in the Intermediate stage in AlQaseem .

- AlMiana ,khaled (2002): Teaching English in Elementary stage Does it Affect mother tongue, Saudi curriculum and teaching methods association. 


\section{ELK ASIA PACIFIC JOURNAL OF SOCIAL SCIENCE}

ISSN 2394-9392 (Online); DOI: 10.16962/EAPJSS/issn. 2394-9392/2015; Volume 5 Issue 1 (2018)

- Lanjawi, Abduulah Ahmad(2001) English language .markets magazine, edition no. (63)

- The Ministry of Education (2014): English language curriculum for intermediate grade, Riyadh: general administration for curriculum

- AlHeela, Mohammad Mahmood,(2011) educational games and technical production.Amman, Dar Almasserah for publishing and distribution.

- Abujadu,Saleh(2005):Educational Esychology Science, Amman ,Dar almaseera for publishing and distribution.

- Jabber,Jabber Abdulhameed,kazem, Ahmad khairi(2002) :research methods in education and psychology, Cairo,Dar Alnahda Alarabia

- Obaidat, Thuqan(2003): Scientific Research Cocept , Tools and Methods ,Riyadh, Dar Osama
- Alassaf,saleh hamad(2003) :Approach to Behavioural Science Research , edition 3 ,Riyadh, Alobaikan bookstore.

- AlZeidi $\operatorname{Eid}(2003)$ : Teaching English in the kingdom of Saudi Arabia, Riyadh, King Saud University magazine. Educational science, first edition.

- Cooper, c. (1987): counselinglearning in second languages, apple river press.

- Kitoe, Kinji. (2003): Why do we teach English/ www.iteslj.orglarticleslkitoe. Why teach.html, 2003.

- Costantino, M. A. (1990). "Teaching English As Aforeign Langnage, Philadelphia; University Of Pennsylvania Press.

- Johnny Grammar's Word Challenge,http://learnenglish.britis hcouncil. org/en/apps/johnnygrammars-word-challenge

Appendix A: Achievement test

Name:

Class:

Lovely students would you kindly answer these questions:

\section{A) Choose the correct answer:}




\begin{tabular}{|c|c|c|c|c|}
\hline \multirow{2}{*}{$\begin{array}{l}\text { Q. } \\
\text { No }\end{array}$} & \multirow[t]{2}{*}{ Question } & \multicolumn{3}{|l|}{ Choices } \\
\hline & & $\mathbf{A}$ & B & $\mathrm{C}$ \\
\hline 1 & I need ............... to go shopping . & a money & $\begin{array}{l}\text { some } \\
\text { money }\end{array}$ & monies \\
\hline 2 & What are the $\ldots \ldots \ldots \ldots$ for the game. & rules & some rules & - rule \\
\hline 3 & I put........... on the table & the sugar & sugars & a sugar \\
\hline 4 & Ali goes by bike . He hasn't got ........... & cars & a car & an car \\
\hline 5 & -He is.............. the house & Over & In & Under \\
\hline 6 & -you should drive ............in the rain & slowing & Slowly & slowest \\
\hline 7 & The weekend went very ... & Quickly & Quick & quicking \\
\hline 8 & $\begin{array}{l}\text { she } \ldots \ldots \ldots \ldots \ldots \ldots \ldots \text { A lot of cheese } \\
\text { every day. }\end{array}$ & eat & Eating & eats \\
\hline 9 & $\begin{array}{l}\text { There } \ldots \ldots \ldots \ldots \ldots \ldots \ldots \ldots . \ldots 30 \text { students } \\
\text { in my class. }\end{array}$ & Is & Are & Am \\
\hline 10 & I go to the gym.... & Today & Daily & Yesterday \\
\hline 11 & I like ...................... Food & Fresh & New & Today \\
\hline 12 & the chair was very $\ldots \ldots \ldots \ldots \ldots \ldots \ldots$ & Weight & Heavy & Heavier \\
\hline 13 & $\begin{array}{l}\text { We had a very } \ldots \ldots \ldots \ldots \ldots \text { cake for } \\
\text { breakfast }\end{array}$ & Hotter & Hottest & Hot \\
\hline 14 & $\begin{array}{l}\text { I } \ldots \ldots \ldots \ldots \ldots \ldots \text { an email to her } \\
\text { yesterday. }\end{array}$ & Wrote & Write & Written \\
\hline 15 & It has ............. Along time to do it. & Took & Taken & Takes \\
\hline 16 & -Have you ................ Layla. & See & Saw & Seen \\
\hline 17 & $\begin{array}{l}\text { I will be here from Sunday } \ldots \ldots \ldots \ldots \ldots \\
\text { Friday }\end{array}$ & To & After & Between \\
\hline 18 & I don't like going out ................ night & At & Any & By \\
\hline 19 & I will see you ............. Monday & At & In & On \\
\hline 20 & $\begin{array}{l}\text { They went to school } \\
\text { Bus }\end{array}$ & On & By & At \\
\hline
\end{tabular}




\section{B) Circle the correct spelling}

\begin{tabular}{|l|l|l|l|}
\hline $\mathbf{1}$ & thocu & tcohu & Touch \\
\hline 2 & hodyali & holiday & hloaidy \\
\hline 3 & recycle & rcycle & reycle \\
\hline 4 & honest & hnoste & hnstne \\
\hline 5 & arreang & arrange & ararnge \\
\hline 6 & somke & smkoe & smoke \\
\hline 7 & fshre & fesrh & Fresh \\
\hline 8 & frneid & Friend & feirnd \\
\hline 9 & Noise & nisoe & nosie \\
\hline 10 & craing & Caring & ciargn \\
\hline
\end{tabular}

Appendix B: students trend measuring index

Students attitude towards Johnny Grammar Application.

\begin{tabular}{|c|c|c|c|c|}
\hline No. & Statements & agree & neutral & disagree \\
\hline 1 & $\begin{array}{l}\text { Johnny grammar helped me to write correct complete } \\
\text { sentences in English }\end{array}$ & $\bigcirc$ & $\bigcirc$ & $\bigcirc$ \\
\hline 2 & $\begin{array}{l}\text { Johnny grammar helped me to spell words quickly and } \\
\text { accurately }\end{array}$ & $\bigcirc$ & $\bigcirc$ & $\bigcirc$ \\
\hline 3 & $\begin{array}{l}\text { Johnny grammar helped me to learn new English } \\
\text { vocabulary }\end{array}$ & $\bigcirc$ & $\bigcirc$ & $\bigcirc$ \\
\hline 4 & $\begin{array}{l}\text { Johnny grammar helped me to Study English } \\
\text { independently }\end{array}$ & $\bigcirc$ & $\bigcirc$ & $\bigcirc$ \\
\hline 5 & Johnny grammar made love learning English language & O & O & $\bigcirc$ \\
\hline 6 & I would recommend Johnny grammar to my friends. & O & $\bigcirc$ & $\bigcirc$ \\
\hline 7 & $\begin{array}{l}\text { I would like to use another educational app on British } \\
\text { Council website. }\end{array}$ & O & $\bigcirc$ & $\bigcirc$ \\
\hline
\end{tabular}


1-What are your suggestions to improve the app?

THANK YOU

Appendix C: students' parents trend measuring index

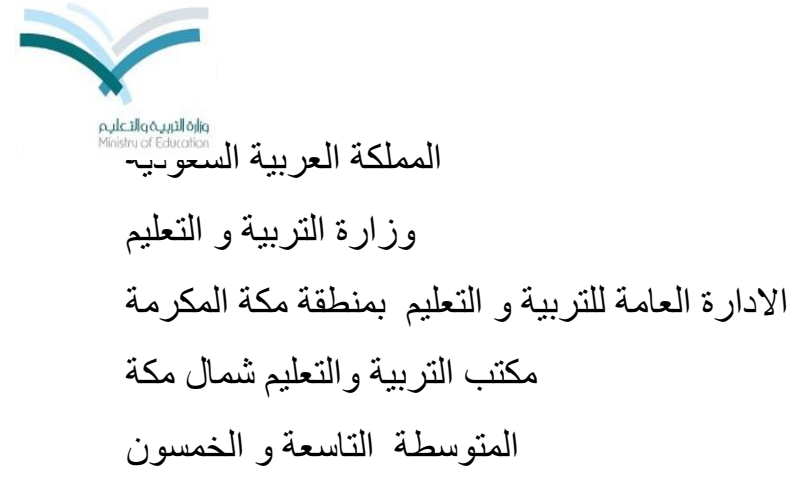

المكرم / ولي أمر الطالبة

نشكر لكم تعاونكم و تجاويكم معنا في الموافقة على اشرالك ابنتكم و متابعتكم لها في فترة استخلام تطبيق

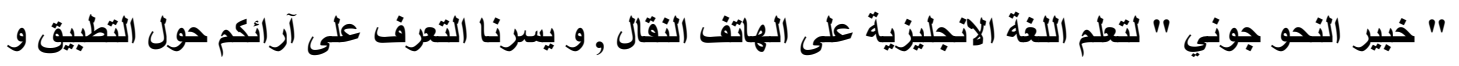
أثره .

نرجو قراءة العبارات التالية باهتمام ثم التعبير عن رأيكم باختيار إجابه واحده من الاجابات الموضحة أمام كل مفردة. علما بأنه لا توجد إجابة خاطئة و أخرى صحيحة. فالإجابة الصحيحة هي التي تعبر عن وجهة بندئ نظرك بدقة

في الحقل الأي بعبر عن وجهة نظرتك لملاحظة : ضع إشارة

\begin{tabular}{|c|c|c|c|c|}
\hline لا أو افق & محايد & أوافق & العبار ات & r \\
\hline O & $\mathrm{O}$ & O & تشعر ابنتي بمتعة عند استخدام التطبيق & 1 \\
\hline O & $\mathrm{O}$ & O & ساهم التطبيق في تشجيع ابنتي على تعلم اللغة الاتجليزية & 2 \\
\hline
\end{tabular}




\begin{tabular}{|c|c|c|c|c|}
\hline O & $\mathrm{O}$ & O & رفع من المستوى التحصيلي لابنتي في مادة اللغة الانجليزية & 3 \\
\hline $\mathrm{O}$ & O & O & 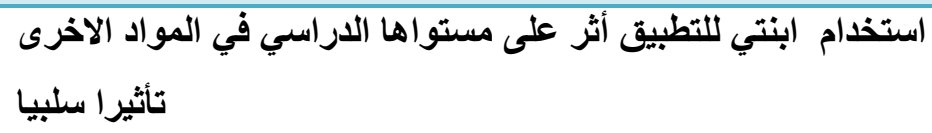 & 4 \\
\hline O & O & O & أنصح باستخدام التطبيق لأنه مفيد لتعلم اللغة الاتجليزية & 5 \\
\hline
\end{tabular}

ماهي اقتراحاتكم لتظوير البرنامج

\section{LIST OF TABLES}

\begin{tabular}{|l|l|l|l|l|}
\hline Group & $\begin{array}{l}\text { No. of students } \\
\text { before study }\end{array}$ & $\begin{array}{l}\text { No. of student } \\
\text { after study }\end{array}$ & Students trend & $\begin{array}{l}\text { Students' } \\
\text { parents } \\
\text { trend }\end{array}$ \\
\hline Standard & 50 & 50 & - & - \\
\hline Experimental & 50 & 50 & 50 & 50 \\
\hline
\end{tabular}

Table 1: Samples domain details of the study.

\begin{tabular}{|l|l|l|l|l|l|}
\hline Group & Average & $\begin{array}{l}\text { Std. } \\
\text { deviation }\end{array}$ & Std. error & T values & Significance \\
\hline Experimental & 6.67 & 1.9315 & 0.2732 & 0.298 & 0.766 \\
\hline Standard & 6.57 & 1.3740 & 0.1943 & & \\
\hline
\end{tabular}

Table 2: T-test results of the pre-test averages.

\begin{tabular}{|c|r|r|r|r|}
\hline Skills & $\begin{array}{r}\text { Multiple } \\
\text { Choice }\end{array}$ & $\begin{array}{r}\text { Number of } \\
\text { Questions }\end{array}$ & Estimated \\
Weight & Points \\
\hline $\begin{array}{c}\text { Grammar } \\
\text { and }\end{array}$ & $1-20$ & 20 & $66.6 \%$ & 10 \\
Vocabulary \\
Skills
\end{tabular}


ELK ASIA PACIFIC JOURNAL OF SOCIAL SCIENCE

ISSN 2394-9392 (Online); DOI: 10.16962/EAPJSS/issn. 2394-9392/2015; Volume 5 Issue 1 (2018)

\begin{tabular}{|r|r|r|r|r|}
\hline Spelling skills & $21-30$ & 10 & $33.4 \%$ & 5 \\
\hline
\end{tabular}

Table 3: Achievement test statistics

\begin{tabular}{|c|c|c|c|c|c|}
\hline Paragraph & $\begin{array}{r}\text { Difficulty } \\
\text { Factor }\end{array}$ & Ease Factor & Paragraph & $\begin{array}{r}\text { Difficulty } \\
\text { Factor }\end{array}$ & $\begin{array}{r}\text { Ease } \\
\text { Factor }\end{array}$ \\
\hline 1 & 0.54 & & 16 & 0.68 & 0.32 \\
\hline 2 & 0.52 & 0.48 & 7 & 0.64 & 0.36 \\
\hline 3 & 0.44 & 0.56 & 8 & 0.58 & 0.42 \\
\hline 4 & 0.51 & 0.49 & 9 & 0.62 & 0.38 \\
\hline 5 & 0.48 & 0.52 & 0 & 0.54 & 0.46 \\
\hline 6 & 0.60 & 0.40 & 1 & 0.62 & 0.38 \\
\hline 7 & 0.64 & 0.36 & 2 & 0.56 & 0.44 \\
\hline 8 & 0.56 & 0.44 & 3 & 0.58 & 0.42 \\
\hline 9 & 0.54 & 0.46 & 4 & 0.51 & 0.49 \\
\hline 0 & 0.58 & 0.42 & 5 & 0.54 & 0.46 \\
\hline $\mathbf{1}$ & 0.52 & 0.48 & 6 & 0.50 & 0.50 \\
\hline 2 & 0.50 & 0.50 & 7 & 0.48 & 0.52 \\
\hline$\overline{3}$ & 0.54 & 0.46 & 8 & 0.52 & 0.48 \\
\hline 4 & 0.56 & 0.44 & 9 & 0.54 & 0.46 \\
\hline 5 & 0.60 & 0.40 & 0 & 0.50 & 0.50 \\
\hline
\end{tabular}

Table 4: Ease and difficulty factors of the ahcievement test questions.

\begin{tabular}{|r|rr|}
\hline Skills & Cronbach's alpha \\
\hline \hline Skills, Grammar and Vocabulary & $\mathbf{0 . 8 7}$ \\
\hline Spelling Skills & $\mathbf{0 . 9 1}$ \\
\hline
\end{tabular}




\section{Total Scale}

Table 5: Achievement test stability statistics

\begin{tabular}{|c|c|c|c|}
\hline \multicolumn{2}{|c|}{ Attitudes of the students } & \multicolumn{2}{|c|}{ Attitudes of parents } \\
\hline Paragraph & Correlation & Paragraph & Correlation \\
\hline 1 & 0 & 1 & $0.72 * *$ \\
\hline 2 & 0 & 2 & $0.71 * *$ \\
\hline 3 & 0 & 3 & $0.78 * *$ \\
\hline 4 & 0 & 4 & $0.70 * *$ \\
\hline 5 & 0 & 5 & $0.72 * *$ \\
\hline 6 & 0 & & \\
\hline 7 & 0 & & \\
\hline
\end{tabular}

Table 6: Internal consistency of the acheveiement test questions.

\begin{tabular}{|r||r||r||r|}
\hline Appreciation & Agree & Neutral & Disagree \\
\hline \hline Estimated weight & 3 & 2 & 1 \\
\hline
\end{tabular}

Table 7: Marking index of the achievement test.

\begin{tabular}{|r||r|r|}
\hline Group & Average & Std. deviation \\
\hline \hline Experimental & 6.89 & 1.2628 \\
\hline Standard & 4.08 & 0.9549 \\
\hline
\end{tabular}

Table 8: Average and std. deviation of the post-achievement test for experimental and standard group for grammar and vocablary skills.

\begin{tabular}{|l||l|l||l||l|l|}
\hline Group & Average & $\begin{array}{l}\text { Std. } \\
\text { deviation }\end{array}$ & Std. error & T values & Significance \\
\hline
\end{tabular}




\begin{tabular}{|c|c|c|c|c|c|}
\hline Experimental & 6.89 & 1.2628 & 0.1785 & \multirow{2}{*}{12.550} & \multirow{2}{*}{$0.001 *$} \\
\hline Standard & 4.08 & 0.9549 & 0.1350 & & \\
\hline
\end{tabular}

Table 9: T-test results for the difference of the averages of the experimental and standard groups results for English language grammar and vocabulary skills.

\begin{tabular}{|l||l|l||}
\hline Group & Average & Std. deviation \\
\hline \hline & 3.46 & 0.5700 \\
\hline \hline S & 1.98 & 0.5047 \\
\hline
\end{tabular}

Table 10: Averages and std. deviation of the post-achievement for the experimental and standard groups for spelling skills.

\begin{tabular}{|l||l|l||l|l|l|}
\hline Group & Average & $\begin{array}{l}\text { Std. } \\
\text { deviation }\end{array}$ & Std. error & T values & Significance \\
\hline \hline Experimental & 3.46 & 0.5700 & 0.0806 & 13.746 & $0.001 *$ \\
\hline \hline Standard & 1.98 & 0.5047 & 0.0713 & & \\
\hline
\end{tabular}

Table 11: T-test results for the difference of the averages of the experimental and standard groups results for English language spelling skills.

\begin{tabular}{|l||l||l||}
\hline Group & Average & Std. deviation \\
\hline \hline 1 & 10.35 & 1.7357 \\
\hline \hline & 6.06 & 1.4020 \\
\hline
\end{tabular}

Table 12: Averages and std. deviation of the post-acheivement test for experimental and standard groups for English learning skills.

\begin{tabular}{||l||l|l|l||l|l||}
\hline Group & Average & $\begin{array}{l}\text { Std. } \\
\text { deviation }\end{array}$ & Std. error & T values & Significance \\
\hline \hline Experimental & 10.35 & 1.7357 & 0.2457 & 13.595 & $0.001 *$ \\
\hline \hline Standard & 6.06 & 1.4020 & 0.1982 & & \\
\hline
\end{tabular}

Table 13: T-test results of the post-achievement test for experimental and standard groups for English learning skills. 
ELK ASIA PACIFIC JOURNAL OF SOCIAL SCIENCE

ISSN 2394-9392 (Online); DOI: 10.16962/EAPJSS/issn. 2394-9392/2015; Volume 5 Issue 1 (2018)

\begin{tabular}{|l|l|l|l||}
\hline Skills & Achievement & Average & Eta squared \\
\hline \multirow{2}{*}{$\begin{array}{l}\text { Grammar and } \\
\text { Vocabulary Skills }\end{array}$} & pre- achievement & $\mathbf{2 . 0 3}$ & \multirow{2}{*}{$\mathbf{0 . 8 1 1}$} \\
\cline { 2 - 4 } & post-achievement & $\mathbf{3 . 4 6}$ & \\
\hline \hline \multirow{2}{*}{ Spelling skills } & pre- achievement & $\mathbf{4 . 6 4}$ & \multirow{2}{*}{$\mathbf{0 . 7 8 5}$} \\
\cline { 2 - 4 } & post-achievement & $\mathbf{6 . 8 9}$ & \\
\hline \hline \multirow{2}{*}{ Total Skills } & pre- achievement & $\mathbf{6 . 6 7}$ & \multirow{2}{*}{$\mathbf{0 . 8 0 8}$} \\
\cline { 2 - 5 } & post-achievement & $\mathbf{1 0 . 3 5}$ & \\
\hline
\end{tabular}

Table 14: Eta squared results of the pre- and post-achievement test of the experimental group.

\begin{tabular}{|l|l|l|l|}
\hline $\mathrm{n}$ & Paragraph & Average & Std. deviation \\
\hline \hline 1 & Write correct complete sentences in English & 2,34 & 0.848 \\
\hline 2 & Spell words quickly and accurately & 2,42 & 0.835 \\
\hline 3 & Learn new English vocabulary & 2,72 & 0.640 \\
\hline 4 & Study English independently & 2,66 & 0.717 \\
\hline 5 & Love learning English & 2,80 & 0.606 \\
\hline 6 & I would recommend it to my friends. & 2,94 & 0.314 \\
\hline 7 & $\begin{array}{l}\text { I would like to use another educational app on the British } \\
\text { Council website. }\end{array}$ & 2,76 & 0.555 \\
\hline \hline & Total Average & 2,66 & 0.650 \\
\hline
\end{tabular}

Table 15: Averages and standard deviations measuring the trend of the students regarding use of the Johnny application.

\begin{tabular}{|c|c|c|c|}
\hline No. & Statements & Average & Std. deviation \\
\hline 1 & تشعر ابنتي بمتعة عند استخدام التطبيق & 2,80 & 0.571 \\
\hline 2 & ساهم التطبيق في تثجيع ابنتي على تعلم اللغة الانجليزية & 2,78 & 0.616 \\
\hline 3 & رفع من المستوى التحصيلي لابنتي في مادة اللغة الانجليزية & 2,44 & 0.884 \\
\hline
\end{tabular}




\section{ELK ASIA PACIFIC JOURNAL OF SOCIAL SCIENCE}

ISSN 2394-9392 (Online); DOI: 10.16962/EAPJSS/issn. 2394-9392/2015; Volume 5 Issue 1 (2018)

\begin{tabular}{||l|l|l|l||}
\hline 4 & (ستخدام ابنتي للتطبيق أثر على مستواها الاراسي في المواد الاخرى تأثيرا & 2,04 & 0.402 \\
\hline 5 & سلبيا أنصح باستخدام التطبيق لأنه مفيد لتعلم اللغة الانجليزية & 2,92 & 0.396 \\
\hline \hline & Total Average & 2,60 & 0.574 \\
\hline
\end{tabular}

Table 16: Averages and standard deviations of the trend measuring of the students' parents when using Johnny application. 